\title{
Pengaruh Media Audiovisual pada Materi Shalat terhadap Minat dan Hasil Belajar Peserta Didik
}

\author{
Viola Amnda1, Wirdati ${ }^{2}$ \\ amndaviola@gmail.com ${ }^{1}$,wirdati@fis.unp.ac.id ${ }^{2}$ \\ Universitas Negeri Padang1,2
}

\begin{tabular}{l}
\hline ARTICLE INFO \\
\hline Article history: \\
Received, 21 October 2021 \\
Revised, 10 November \\
2021 \\
Accepted, 30 November \\
2021 \\
\hline Keywords: \\
Media Audiovisual, Materi \\
Salat, Minat Belajar, Hasil \\
Belajar, Peserta Didik \\
\hline Clonflict of Interest: \\
None
\end{tabular}

Funding:

None

\begin{abstract}
Penelitian ini dilakukan untuk mengetahui pengaruh media audiovisual pada materi shalat terhadap minat dan hasil belajar peserta didik. Lokasi penelitian ini di Sekolah Menengah Pertama Negeri 6 Bukittinggi. Data diperoleh dari penyebaran angket, observasi, dan dokumentasi. Penelitian ini menggunakan jenis penelitian kuantitatif dengan desain penelitian Single Group Pretest-Postest Design. Pengambilan sampel dilakukan dengan teknik purposive sampling. Untuk uji hipotesis peneliti menggunakan uji t-Test dan uji Manova Multivariate. Hasil uji Manova Multivariate menunjukkan nilai Sig 0,000 < 0,05 maka didapatkan kesimpulan bahwa $\mathrm{H}_{0}$ ditolak dan $\mathrm{H}_{\mathrm{a}}$ diterima. Hal ini menunjukkan bahwa terdapat pengaruh yang signifikan penggunaan media audiovisual pada materi salat terhadap minat dan hasil belajar peserta didik di SMP Negeri 6 Bukittinggi.
\end{abstract}

Corresponding Author: Viola Amnda, Departement Islamic Education, Faculty of Social Science Universitas Negeri Padang, Indonesia, Email: amndaviola@gmail.com Phone: $+6283182644411$

\section{Pendahuluan}

Kemajuan ilmu pengetahuan dan teknologi memiliki pengaruh yang sangat besar dalam berbagai bidang kehidupan manusia. Pendidikan sebagai salah satu bagian yang tidak terpisahkan dari proses pendewasaan manusia tentu di satu sisi memiliki andil yang besar bagi pengembangan ilmu pengetahuan dan teknologi tersebut, namun di sisi lain pendidikan juga perlu memanfaatkan kemajuan ilmu pengetahuan dan teknologi agar mampu mencapai tujuannya secara efektif dan efisien (Muhson, 2010: 1).

Kemajuan ilmu pengetahuan dan teknologi telah berpengaruh terhadap penggunaan alatalat bantu mengajar di sekolah-sekolah dan lembaga-lembaga pendidikan lainnya. Sanaky (dalam Rijal, 2020:81) mengatakan saat ini pembelajaran di sekolah mulai disesuaikan dengan perkembangan teknologi informasi, sehingga terjadi perubahan dan pergeseran paradigma pendidikan. Hal ini mengindikasikan bahwa penggunaan teknologi informasi dalam proses pembelajaran di kelas, sudah menjadi suatu kebutuhan sekaligus tuntutan di era global ini (Muhson, 2010: 1). Namun kenyataan di lapangan masih banyak guru yang belum menerapkan pembelajaran berbasis teknologi informasi. Dalam hal ini, media pembelajaran merupakan salah satu pendukung yang efektif dalam membantu terjadinya proses belajar (Mahnun, 2012: 27). 
Rusyan (dalam Mahnun, 2012) mengatakan bahwa Penggunaan media dalam pembelajaran di kelas merupakan sebuah kebutuhan yang tidak dapat diabaikan, hal ini dapat dipahami mengingat proses belajar yang dialami peserta didik tertumpu pada berbagai kegiatan menambah ilmu dan wawasan untuk bekal hidup di masa sekarang dan masa akan datang, salah satu upaya yang harus ditempuh adalah bagaimana menciptakan situasi belajar yang memungkinkan terjadinya proses pengalaman belajar pada diri peserta didik dengan menggerakkan segala sumber belajar dan cara belajar yang efektif dan efisien.

Dalam hal ini, media pembelajaran merupakan salah satu pendukung yang efektif dalam membantu terjadinya proses belajar (Mahnun, 2012: 27). Mahnun juga menambahkan pada proses pembelajaran, media pembelajaran merupakan wadah dan penyalur pesan dari sumber pesan, dalam hal ini guru, kepada penerima pesan yaitu peserta didik. Dalam batasan yang lebih luas, batasan media pembelajaran sebagai segala sesuatu yang dapat digunakan untuk merangsang pikiran, perasaan, perhatian, dan kemauan peserta didik sehingga mendorong terjadinya proses belajar pada diri peserta didik (Susilana \& Riyana, 2008: 6).

Menurut Asmara, (2015: 157) media pembelajaran juga menempati posisi yang strategis dalam proses pembelajaran karena menjadi perantara informasi pengetahuan dari guru kepada peserta didik. Banyak manfaat yang diberikan media pembelajaran kepada peserta didik seperti yang dikemukakan Sudjana dan Rivai (dalam Asmara, 2015: 157) antara lain menarik perhatian peserta didik sehingga dapat menumbuhkan motivasi belajar dan menjadi metode alternatif dalam belajar karena peserta didik tidak semata-mata mendapatkan pembelajaran dari satu sumber.

Mengolah komponen media pembelajaran tentu salah satunya dengan menentukan jenisjenis media pembelajaran yang akan digunakan dalam pembelajaran. Dilihat dari jenisnya media dibagi kedalam media Auditif, visual, dan Audio visual (Mumtahanah, 2014: 91-104). Media Auditif adalah media yang banyak mengandalkan kemampuan suara saja, seperti radio, cassette recorder, piringan hitam, dan lain-lain. Media visual adalah media yang hanya mengandalkan indera penglihatan, seperti film bisu, slide, foto/gambar, grafik, globe/peta, chart/bagan, diagram, dan lain-lain. Sedangkan media audio visual adalah media yang mempunyai kemampuan yang lebih baik karena meliputi kedua jenis media yang pertama dan kedua (Prupuh, 2007: 67-68)

Danim (dalam Mahunun, 2012: 27) menyebutkan manfaat media dalam pembelajaran adalah sebagai berikut (1) Meningkatkan mutu pendidikan dengan cara meningkatkan kecepatan belajar (rate of learning), (2) Memberi kemungkinan pendidikan yang sifatnya lebih individual, (3) Memberi dasar pengajaran yang lebih ilmiah, (4) Pengajaran dapat dilakukan secara mantap, (5) Meningkatkan terwujudnya kedekatan belajar (immediacy learning), dan (6) Memberikan penyajian pendidikan lebih luas. Banyak sekali manfaat media pembelajaran yang dapat diterapkan dalam materi pembelajaran salah satunya materi salat pada mata pelajaran Pendidikan Agama Islam. Majid dan Andayani (dalam Yulianti, 2018: 200) mengatakan bahwa mata pelajaran Pendidikan Agama Islam (PAI) merupakan salah satu mata pelajaran yang sangat penting untuk menyiapkan peserta didik dalam hal memahami, menghayati, dan mengimani hingga mengamalkan ajaran Islam melalui kegiatan bimbingan, pengajaran dan latihan.

Pada pembelajaran Pendidikan Agama Islam materi salat juga diperlukannya minat dari peserta didik. Dilihat dari defenisi minat menurut Slameto (dalam Ricardo \& Rini, 2017: 190) minat adalah, suatu rasa lebih suka, rasa ketertarikan, perhatian, fokus, ketekunan, usaha, pengetahuan, keterampilan, motivasi, pengatur perilakumdan hasil interaksi seseorang atau individu dengan konten atau kegiatan tertentu. Sardiman (dalam Astuti, 2015: 71) juga menjelaskan bahwa minat merupakan suatu kondisi yang terjadi apabila seseorang melihat ciri-ciri atau arti sementara situasi yang dihubungkan dengan keinginan dan kebutuhannya sendiri.

Kenyataan yang ditemukan dilapangan masih banyak sekolah atau guru yang belum memanfaatkan media berbasis teknologi informasi, terutama pada mata pelajaran Pendidikan Agama Islam, dimana guru cenderung menggunakan metode ceramah dalam 
pembelajaran, salah satu contohnya adalah pada materi salat, menggunakan metode ceramah dalam materi salat pada mata pelajaran Pendidikan Agama Islam tentu tidak efektif, karena pada materi ini diminta untuk pemahaman yang jelas, digambarkan, serta langsung di praktekkan, jika guru hanya menggunakan metode ceramah tanpa menggambarkan lebih rinci tentu tidak akan mencapai tujuan pembelajaran dan peserta didik akan susah mengerti materi salat ini. Untuk itu diperlukannya penggunaan media pembelajaran berbasis teknologi informasi sehingga pembelajaran lebih inovatif, bervariasi, tidak membosankan, dan peserta didik akan cepat mengerti terkait pembelajaran yang diberikan.

Alasan peneliti memilih SMP Negeri 6 Bukittinggi sebagai tempat penelitian adalah karena sekolah ini memiliki kualitas yang baik dan sudah memperoleh berbagai jenis prestasi. Selain itu sekolah ini juga memiliki banyak peminat terutama wilayah Bukittinggi, Agam dan sekitarnya, akan tetapi setelah peneliti melakukan observasi awal di SMP Negeri 6 Bukittinggi terdapat masalah terhadap minat dan hasil belajar peserta didik dalam pembelajaran Pendidikan Agama Islam terutama pada materi salat yang berdampak pada rendahnya hasil belajar peserta didik. Hal ini juga dikuatkan oleh bapak Mauli Wardi, S.Pd.I selaku guru Pendidikan Agama Islam kelas VII di SMP Negeri 6 Bukittinggi. Berdasarkan permasalahan tersebut maka pihak sekolah memerlukan strategi untuk meningkatkan minat dan hasil belajar peserta didik. Oleh karena itu peneliti tertarik untuk melakukan suatu penelitian ilmiah untuk melihat salah satu upaya dalam meningkatkan minat dan hasil belajar peserta didik pada materi salat dengan menggunakan media pembelajaran Audio Visual.

\section{Tinjauan Pustaka}

\section{A. Media Pembelajaran}

\section{1) Pengertian Media Pembelajaran}

Kata media pembelajaran berasal dari bahasa latin"medius" yang secara harfiah berarti "tengah", perantara atau pengantar. Dalam bahasa Arab, media perantara atau pengantar pesan dari pengirim kepada penerima pesan (Arsyad, 2011: 23). Gerlach dan Ely (dalam Arsyad, 2011: 23) mengatakan bahwa media apabila dipahami secara garis besar adalah manusia, materi, atau kejadian yang membangun kondisi yang membuat peserta didik mampu memperoleh pengetahuan, keterampilan, atau sikap. Dari pengertian diatas dapat disimpulkan bahwa Media Pembelajaran adalah segala sesuatu yang dapat digunakan untuk menyalurkan pesan dari pengirim ke penerima sehingga merangsang pikiran, perasaan, perhatian, dan minat serta kemauan peserta didiksedemikian rupa sehingga proses belajar terjadi dalam rangka mencapai tujuan pembelajaran secara efektif.

\section{2) Jenis-Jenis Media Pembelajaran}

Menurut Susanti dan Zulfiana, (2018: 5) jenis-jenis media pembelajaran terbagi menjadi 3 yaitu. 1) media visual, 2) media audio 3) media audio visual. a) Media Visual, adalah suatu alat atau sumber belajar yang di dalamnya berisikan pesan, informasi khususnya materi pelajaran yang di sajikan secara menarik dan kreatif dan diterapkan dengan menggunakan indera pengelihatan. Jenis-jenis media visual yaitu gambar/foto, peta konsep, diagram, grafik, poster dan peta/globe. b) Media Audio, Media Audio atau media dengar adalah jenis media pembelajaran atau sumber belajar yang berisikan pesan atau materi pelajaran yang disajikan secara menarik dan kreatif dan diterapkan dengan menggunakan indera pendegaran saja, karena media ini hanya berupa suara. Jenis-jenis media audio yaitu radio dan alat perekam pita magnetik. c) Media Audiovisual, adalah jenis media pembelajaran atau sumber belajar yang berisikan pesan atau materi pelajaran yang dibuat secara menarik dan kreatif dengan menggunakan indra pendengaran dan penglihatan, media ini berupa suara dan gambar. Jenis-jenis media audio visual yaitu televise, video kaset dan film bersuara.

\section{3) Manfaat Media Pembelajaran}

Secara umum, manfaat media dalam proses pembelajaran adalah memperlancar interaksi antara guru dan peserta didik sehingga kegiatan pembelajaran akan lebih 
efektif dan efisien (Muhson, 2010: 4). Muhson juga menambahkan manfaat media pembelajaran secara praktis antara lain: (1) Mengkonkretkan konsep-konsep yang bersifat abstrak, sehingga dapat mengurangi verbalisme. Misalnya dengan menggunakan gambar, skema, grafik, model, dan sebagainya, (2) Membangkitkan motivasi, sehingga dapat memperbesar perhatian individual peserta didik untuk seluruh anggota kelompok belajar sebab jalnnya pelajaran tidak membosankan dan tidak monoton, (3) Memfungsikan seluruh indera peserta didik, sehingga kelemahan dalam salah satu indera (missal: mata atau telinga) dapat diimbangi dengan kekuatan indera lainnya. (4) Mendekatakan dunia teori konsep dengan realita yang sukar diperoleh dengan cara-cara lain selain menggunakan media pembelajaran, (5) Menyajikan informasi belajar secara konsisten dan dapat diulang maupun disimpan menurut kebutuhannya.

\section{B. Audiovisual}

\section{1) Pengertian Audiovisual}

Menurut Purwono, (2014: 130) media audio visual adalah media kombinasi antara audio dan visual yang dikombinasikan dengan kaset audio yang mempunyai unsur suara dan gambar yang bisa dilihat, misalnya rekaman video, slide suara dan sebagainya. Sudirman (dalam Wirdaningsih \& Mardhatillah, 2016: 3) mengatakan bahwa media pembelajaran audio visual adalah sebuah cara pembelajaran dengan menggunakan media yang mengandung unsur suara dan gambar, dimana dalam proses penyerapan materi melibatkan indra penglihatan dan indra pendengaran.

\section{2) Jenis-Jenis Media Audiovisual}

Ada beberapa jenis media audio visual yang dapat digunakan dalam pembelajaran Syaiful Bahri Djamarah (dalam Jannah, 2020: 35) mengungkapkan ada dua jenis media audio visual yaitu audio visual gerak yang menampilkan unsur suara dan gambar yang bergerak seperti film suara dan video cassette. Dan juga audio visual diam yang menampilkan suara gambar diam seperti film bingkai suara (sound slide), film rangkai suara dan cetak suara.

\section{3) Fungsi Media Audiovisual dalam Pembelajaran}

Media audio visual memiliki fungsi dalam pembelajaran, Fungsi media audio visual dalam pembelajaran menurut Yusuf Hadi Miarso (dalam Sahara, 2017: 20) adalah (1) Media audio visual mampumemberikan rangsangan yang bervariasi pada otak, sehingga otak dapat berfungsi secara optimal, (2) Media audio visual dapat mengatasi keterbatasan pengalaman yang dimiliki oleh peserta didik, (3) Media audio visual dapat melampaui batas ruang kelas, (4) Media audio visual memungkinkan adanya interaksi langsung antara peserta didik dengan lingkungannya, (5) Media audio visual menghasilkan keseragaman pengamatan, (6) Media audio visual dapat membangkitkan keinginan dan minat baru, (7) Media audio visual membangkitkan motivasi dan merangsang untuk belajar, (8) Media audio visual memberikan pengalaman yang integral dari sesuatu yang konkret maupun abstrak, (9) Media audio visual memberikan kesempatan peserta didik untuk belajar mandiri, pada tempat dan waktu serta kecepatan yang ditentukan sendiri, (10) Media audio visual dapat meningkatkan kemampuan ekspresi diri guru maupun peserta didik.

\section{4) Langkah-Langkah Menggunakan Media Audio Visual}

Dalam menggunakan media audio visual memiliki tata cara atau langkah-langkah, agar terencana dan sistematik, Djamarah (dalam Abdurrohman, 2017:40) mengatakan ada enam langkah yang dapat di tempuh guru dalam mengajar menggunakan media, langkah-langkah tersebut adalah sebagai berikut: (1) merumuskan tujuan pembelajaran dengan memanfaatkan media, (2) persiapan guru, (3) persiapan kelas, (4) langkah penyajian pelajaran dan pemanfaatan media, (5) langkah kegiatan peserta didik, (6) langkah evaluasi pembelajaran.

Menurut Fitria, (2014:61) langkah penggunaan media audio visual adalah sebagai berikut: a) Guru mempersiapkan laptop, sound, kabel dan vidio yang akan ditayangkan, 
Viola Amnda dan Wirdati: Pengaruh Media Audiovisual pada Materi Shalat terhadap Minat...

b) Memperhatikan posisi duduk peserta didik dalam keadaan nyaman, c) Sebelum menayangkan vidio, terlebih dahulu guru menyampaikan tujuan pembelajaran, d) Terakhir guru menayangkan vidio pembelajaran.

Berdasarkan langkah penggunaan media audio visual di atas, pada penelitian ini langkah awal yang akan peneliti lakukan dalam penggunaan media audio visual adalah: (1) memilih vidio pembelajaran yang berkenaan dengan materi salat berdasarkan tujuan pembelajaran, (2) menganalisis isi vidio pembelajaran berkaitan dengan materi salat, (3) persiapan memulai pembelajaran, seperti menyiapkan laptop, kabel, dan LCD Proyektor, (4) penyajian, yaitu menayangkan vidio pembelajaran, (5) Tindak lanjut, yaitu dengan evaluasi pembelajaran setelah menggunakan media pembelajaran audio visual.

\section{5) Kelebihan dan Kekurangan Media Audiovisual}

Atoel (dalam Purwono, 2014: 131) menyatakan bahwa media audio visual memiliki beberapa kelebihan atau kegunaan, antara lain: (1) Memperjelas penyajian pesan agar tidak terlalu verbalistis (dalam bentuk kata-kata, tertulis atau lisan) (2) Mengatasi keterbatasan ruang, waktu dan daya indera, seperti: objek yang terlalu besar digantikan dengan gambar, film bingkai, film atau model (3) Media audio visual bisa berperan dalam pembelajaran tutorial. Sanjaya (dalam Andayani, 2017: 165) juga mengemukakan kelebihan dari penggunaan media audio visual yakni, (1) Dapat memberikan pengalaman beajar yang tidak mungkin dapat dipelajari secara langsung, (2) Memungkinkan belajar lebih bervariatif sehingga dapat menambah motivasi dan gairah belajar, (3) dapat berfungsi sebagai sumber belajar secara mandiri tanpa sepenuhnya tergantung pada keahlian guru. Media audio visual juga memiliki kekurangan antara lain: (1) Film/vidio bersuara tidak dapat diselengi dengan keterangan-keterangan yang diucapkan sewaktu film/video diputar, penghentian pemutaran akan mengganggu audiens/peserta didik, (2) audiens/peserta didik tidak akan dapat mengikuti dengan baik jika film/video diputar terlalu cepat, (3) apa yang telah lewat sulit untuk diulang kecuali memutar kembali secara keseluruhan, (4) biaya pembuatan dan peralatannya cukup mahal (Andayani, 2007: 165).

Selanjutnya, penggunaan media audio visual terhadap minat dan hasil belajar peserta didik memliki pengaruh yang signifikan, hal ini di buktikan dengan penelitian terdahulu yang juga mengkaji pengaruh penggunaan media audio visual terhadap minat dan hasil belajar peserta didik oleh Tasya Ainun Jannah mahasiswa IAIN Tulungagung tahun 2020. Pada penelitian Tasya telah dibuktikan bahwa terdapat pengaruh penggunaan media audio terhadap peningkatan minat dan hasil belajar peserta didik (Jannah, 2020).

\section{Pendidikan Agama Islam}

\section{1) Pengertian Pendidikan Agama Islam}

Menurut Dzakiyah Drajat (dalam Rofiq, 2010: 10) Pendidikan Agama Islam adalah suatu usaha untuk membina dan mengasuh peserta didik agar senantiasa dapat memahami ajaran Islam secara menyeluruh. Rofiq, (2010: 12) juga menambahkan bahwa Pendidikan Agama Islam adalah rangkain proses sistematis, terencana, dan komprehensif dalam upaya mentransfer nilai-nilai kepada peserta didik, mengembangkan potensi yang ada pada diri peserta didik sehingga mampu melaksanakan tugasnya di muka bumi dengan sebaik-baiknya, sesuai dengan nilai-nilai ilahiyah yang didasarkan pada ajaran agama (Al-Qur'an dan Hadis) pada semua dimensi kehidupan.

Mata pelajaran Pendidikan Agama Islam secara keseluruhannya dalam lingkup AlQur'an dan Al-Hadis, keimanan, akhlak, fiqih/ibadah, dan sejarah sekaligus menggambarkan bahwa ruang lingkup Pendidikan Agama Islam mencangkup perwujudan keserasian, keselarasan, dan keseimbangan hubungan manusia dengan Allah SWT, diri sendiri, sesame manusia, makhluk lainnya maupun lingkungannya.

2) Tujuan Pendidikan Agama Islam 
Tujuan Pendidikan Agama Islam haruslah sesuai dengan nilai-nilai ajaran Pendidikan Islam, yaitu untuk menjadikan manusia memenuhi tugas kekhalifahannya sebagaimana tujuan diciptakannya manusia (Imelda, 2017: 240). Munzir Hitami (dalam Imelda, 2017: 240) menyatakan bahwa tujuan Pendidikan Agama Islam haruslah mencangkup tiga hal yaitu: 1) tujuan bersifat teologik, yakni kembali kepada Tuhan, 2) tujuan bersifat aspiratif, yaitu kebahagiaan dunia sampai akhirat, dan 3) tujuan bersifat direktif yaitu menjadi makhluk pengabdi kepada Tuhan.

\section{3) Kurikulum Mata Pelajaran Pendidikan Agama Islam}

Menurut Sahlan (dalam Ma'rufah, 2020: 128) ada beberapa bentuk pengembangan kurikulum mata pelajaran Pendidikan Agama Islam, antara lain: (1) penambahan jam pelajaran dan rumpun mata pelajaran PAI, (2) peningkatan kualitas pembelajaran, (3) pengembangan melalui kegiatan ekstrakurikuler, (4) pengembangan melalui pembudayaan nilai-nilai religius.

\section{4) Ruang Lingkup Pendidikan Agama Islam}

Menurut Rusdiana, (2014: 129) ruang lingkup Pendidikan Agama Islam secara umum meliputi keserasian, keselarasan, dan keseimbangan antara hubungan manusia dengan Allah SWT, hubungan manusia dengan sesama manusia, dan hubungan manusia dengan dirinya sendiri, serta hubungan manusia dengan makhluk lain dan lingkungannya. Sedangkan ruang lingkup Pendidikan Agama Islam di SMP meliputi keserasian dalam keseimbangan antara: (1) Hubungan manusia dengan Allah SWT, (2) Hubungan manusia dengan sesama manusia dan (3) Hubungan manusia dengan alam (makhluk selain manusia) dan lingkungan. Adapun ruang lingkup bahan pelajaran Pendidikan Agama Islam di Sekolah Menengah Pertama terfokus pada aspek: a) keimanan, b) Al-Qur'an/Hadis, c) Akhlak, d) Fiqih/Ibadah, e) Sejarah Kebudayaan Islam (Zubaidillah, 2019).

\section{5) Fungsi Pembelajaran Pendidikan Agama Islam}

Menurut Majid (2012: 27) ada tujuh fungsi dari pembelajaran PAI yaitu: 1) Meningkatkan keimanan dan ketakwaan peserta didik kepada Allah SWT yang sebelumnya telah ditanamkan dalam lingkungan keluarga, 2) Menumbuhkan nilai-nilai Islam sebagai pedoman untuk menemukan kebahagiaan di dunia dan akhirat, 3) Adaptasi mental, yaitu menyesuaikan diri baik dengan lingkungan fisik maupun sosial dan mengubah lingkungan berdasarkan ajaran Agama Islam, 4) Melakukan perbaikan, yaitu mengoreksi kesalahan, kekurangan dan kelemahan keyakinan peserta didik, pemahaman dan pengalaman dalam kehidupan sehari-hari, 5) Pemberantasan atau pencegahan hal-hal negatif dari lingkungan dan budaya lain yang dapay merugikan dirinya dan mencegah dari sesuatu yang menghambat perkembangan peserta didik, 6) Mengajarkan tentang ilmu Agama Islam secara umum, sistem dan fungsinya, dan 7) Membimbing dan menyalurkan bakat peserta didik yang memiliki keahlian khusus dalam bidang keislaman agar bakat tersebut dapat tumbuh secara optimal bagi dirinya dan orang lain.

\section{Minat Belajar}

\section{1) Pengertian Minat Belajar}

Minat belajar merupakan dorongan batin yang tumbuh dari seorang peserta didik untuk meningkatkan kebiasaan belajar (Lestari, 2015: 120). Letari juga menambahkan minat belajar akan tumbuh saat peserta didik memiliki keinginan untuk meraih nilai terbaik, atau ingin memenangkan persaingan dalam belajar dengan peserta didik lainnya. Selain itu Jannah, (2020: 43) juga mendefenisikan minat belajar yaitu suatu keinginan yang besar terhadap sesuatu, yang memusatkan pada perasaan serta perhatian yang penuh kemauan tanpa adanya suatu paksaan.

\section{2) Faktor-Faktor yang mempengaruhi Minat Belajar}

Menurut crow and Crow (dalam susilonurinsih, 2006: 14) minat dapat ditimbulkan dari beberapa faktor di antaranya:

a) The Factor of Inner Urges

Faktor ini dititikberatkan dalam usaha individu untuk mempengaruhi kebutuhan fisik dan jasmaninya. Faktor dorongan dari dalam menimbulkan minat untuk belajar 
Viola Amnda dan Wirdati: Pengaruh Media Audiovisual pada Materi Shalat terhadap Minat...

ialah keinginan dan cita-cita serta harapan untuk mendapatkan penghargaan atau prestasi. Seseorang yang mempunyai keinginan terhadap sesuatu akan mendorong individu tersebut aktif melakukan kegiatan untuk mencapai tujuan yang diinginkannya.

b) The Factor of Social Movies

Faktor ini adalah mitif dalam lingkungan. Faktor ini terbagi menjadi 3 yaitu: lingkungan keluarga (rumah), lingkungan sekolah dan lingkungan masyarakat. Lingkungan keluarga (rumah) ikut mempengaruhi minat belajar yaitu suasana rumah, pendidikan orang tua dan sikap orang tua. Misalnya orang tua yang selalu cekcok atau kurang perhatian karena sibuk dengan pekerjaannya atau yang lainnya maka akan membuat anak malas belajar dan tidak berminat untuk belajar karena tidak ada yang mngarahkan/memberi semangat untuk belajar.

c) Emotional Factor

Faktor emosi ini berpengaruh terhadap minat individu. Dalam faktor ini dinyatakan bahwa suatu aktivitas yang dilakukan dengan perasaan senang akan membuahkan hasil yang lebih baik dan sekaligus memperbesar minat terhadap aktivitas tersebut. Faktor emosi yang mempengaruhi minat belajar adalah perasaan senang, perhatian serta keinginan anak untuk belajar

\section{E. Hasil Belajar}

\section{1) Pengertian Hasil Belajar}

Hasil belajar adalah hasil yang dicapai oleh peserta didik setelah melakukan kegiatan belajar dimana hasil tersebut merupakan gambaran penguasaan pengetahuan dan keterampilan dari peserta didik yang berwujud angka dari tes standar yang digunakan sebagai pengukur keberhasilan (Haryoko, 2012: 4). Sedangkan hasil belajar menurut Sudjana (dalam Purwono, 2014: 133) adalah kemampuan yang dimiliki peserta didik setelah peserta didik menerima pengalaman belajarnya, kemampuan ini mencangkup bidang kognitif, afektif dan psikomotor.

\section{2) Faktor-Faktor yang Mempengaruhi Hasil Belajar Peserta Didik}

Menurut Bistari, (2017: 19) ada dua faktor yang mempengaruhi hasil belajar peserta didik yaitu faktor internal dan faktor eksternal, faktor internal, yakni peserta didik itu sendiri. Hasil belajar yang diperoleh peserta didik secara dominan dipengaruhi oleh peserta didik sendiri, seperti bakat, intelektual dan kesiapan. Sedangkan faktor eksternal yang mempengaruhi proses dan hasil belajar peserta didik meliputi faktor keluarga, sekolah dan masyarakat. Dari pendapat di atas dapat disimpulkan bahwa faktor yang mempengaruhi hasil belajar terbagi menjadi dua, yakni faktor internal yang berasal dari dalam diri peserta didik dan faktor eksternal yang berasal dari luar peserta didik.

\section{Metode}

Penelitian ini menggunakan jenis penelitian kuantitatif dengan metode penelitian eksperimen menggunakan desain penelitian Single Group Pretest-Postest Design yaitu dilakukan terhadap satu kelompok tanpa adanya kelompok pembanding. Populasi penelitian adalah peserta didik kelas VII SMP Negeri 6 Bukittinggiyang berjumlah 189 peserta didik. Sampel penelitian peserta didik kelas VII.6 SMP Negeri 6 Bukittinggi, pengambilan sampel dilakukan dengan teknik Purposive Sampling. Untuk minat belajar data dikumpulkan dengan angket dan hasil belajar menggunakan nilai Posttest. Untuk uji hipotesis menggunakan analisis data uji t-Test dan uji Manova.

\section{Hasil dan Pembahasan}

\section{A. Hasil Uji Hipotesis}

1) Pengaruh Penggunaan Media Audio Visual Terhadap Minat Belajar Peserta Didik 
Melihat pengaruh penggunaan media audiovisual pada materi salat terhadap minat belajar peserta didik dan pengaruh penggunaan media audiovisual pada materi salat terhadap hasil belajar peserta didik dilakukan dengan uji $t$-Test.

Tabel 1. Uji $t$-Test Media Audio Visual dan Minat Belajar

\begin{tabular}{|c|c|r|r|r|c|}
\hline \multicolumn{7}{|c|}{ Group Statistics } \\
\hline \multirow{2}{*}{ Hasil } & Nama & $\mathrm{N}$ & Mean & $\begin{array}{c}\text { Std. } \\
\text { Deviation }\end{array}$ & $\begin{array}{c}\text { Std. Error } \\
\text { Mean }\end{array}$ \\
\hline & $\begin{array}{l}\text { audio } \\
\text { visual }\end{array}$ & 28 & 62.64 & 8.314 & 1.571 \\
\cline { 2 - 6 } & $\begin{array}{l}\text { minat } \\
\text { belajar }\end{array}$ & 28 & 79.07 & 5.456 & 1.031 \\
\hline
\end{tabular}

Setelah dilakukan uji $t$-Test untuk media pembelajaran audiovisual dan minat belajar diperoleh mean (rata-rata) untuk audio visual 62,64 dengan nilai t hitung -0,871 dengan Sig. (2-tailed) sebesar 0,000 dan untuk minat belajar dengan mean (rata-rata) sebesar 79,07 dengan nilai t hitung sebesar -0,871 dan Sig. (2-tailed) sebesar 0,000. Kesimpulan yang didapat pada tabel di atas adalah bahwa nilai Sig (2-tailed) 0,000 artinya ada perbedaan antara sebelum dan sesudah mendapatkan perlakuan. Signifikasi data di atas menunjukkan 0,000 $<0,05$ sehingga dapat disimpulkan bahwa "Ada pengaruh yang signifikan penggunaan media audio visual pada materi salat terhadap minat belajar peserta didik".

\section{2) Pengaruh Penggunaan Media Audiovisual Terhadap Hasil Belajar Peserta Didik}

Tabel 2. Uji t-Test Media Audiovisual dan Hasil Belajar

\begin{tabular}{|l|l|r|r|r|c|}
\hline \multicolumn{7}{|c|}{ Group Statistics } \\
\hline \multirow{2}{*}{ Hasil } & $\begin{array}{l}\text { minat } \\
\text { belajar }\end{array}$ & $\mathrm{N}$ & $\begin{array}{c}\text { Mea } \\
\mathrm{n}\end{array}$ & $\begin{array}{c}\text { Std. } \\
\text { Deviation }\end{array}$ & $\begin{array}{c}\text { Std. Error } \\
\text { Mean }\end{array}$ \\
\hline & $\begin{array}{l}\text { audio } \\
\text { visual }\end{array}$ & 28 & 62.6 & 8.314 & 1.571 \\
\cline { 2 - 7 } & $\begin{array}{l}\text { hasil } \\
\text { belajar }\end{array}$ & 28 & 8.61 & 2.250 & .425 \\
\hline
\end{tabular}

Setelah dilakukan Uji $t$-Test untuk media pembelajaran audiovisual dan hasil belajar diperoleh mean (rata-rata) untuk audio visual 62,61 dengan nilai t hitung 33, 196 dengan Sig. (2-tailed) sebesar 0,000 dan untuk hasil belajar dengan mean (rata-rata) sebesar 8,61 dengan nilai t hitung sebesar 33,196 dan Sig. (2-tailed) sebesar 0,000. Kesimpulan yang didapat pada tabel di atas adalah bahwa nilai Sig (2-tailed) 0,000 artinya ada perbedaan antara sebelum dan sesudah mendapatkan perlakuan. Signifikasi data di atas menunjukkan 0,000 $<0,05$ sehingga dapat disimpulkan bahwa "Ada pengaruh yang signifikan penggunaan media audio visual pada materi salat terhadap hasil belajar peserta didik".

\section{3) Pengaruh Penggunaan Media Audiovisual Terhadap Minat dan Hasil Belajar Peserta Didik}

Melihat pengaruh penggunaan media audiovisual pada materi salat terhadap minat dan hasil belajar peserta didik dilakukan dengan uji Maniva.

Tabel 3. Uji Multivariate Manova pengaruh media audio visual terhadap hasil dan minat belajar 
Viola Amnda dan Wirdati: Pengaruh Media Audiovisual pada Materi Shalat terhadap Minat...

\begin{tabular}{|c|c|c|c|c|c|c|}
\hline \multicolumn{7}{|c|}{ Multivariate Tests ${ }^{a}$} \\
\hline \multicolumn{2}{|l|}{ Effect } & Value & $\mathrm{F}$ & $\begin{array}{c}\text { Hypothesis } \\
\text { df }\end{array}$ & $\begin{array}{l}\text { Error } \\
\text { df }\end{array}$ & Sig. \\
\hline \multirow[t]{4}{*}{$\begin{array}{l}\text { Interce } \\
\text { pt }\end{array}$} & Pillai's Trace & .992 & $\begin{array}{r}3190.84 \\
4 \mathrm{~b}\end{array}$ & 2.000 & 53.000 & .000 \\
\hline & Wilks' Lambda & .008 & $\begin{array}{r}3190.84 \\
4 \mathrm{~b}\end{array}$ & 2.000 & 53.000 & .000 \\
\hline & $\begin{array}{l}\text { Hotelling's } \\
\text { Trace }\end{array}$ & $\begin{array}{c}120.40 \\
9\end{array}$ & $\begin{array}{r}3190.84 \\
4 \mathrm{~b}\end{array}$ & 2.000 & 53.000 & .000 \\
\hline & $\begin{array}{l}\text { Roy's Largest } \\
\text { Root }\end{array}$ & $\begin{array}{c}120.40 \\
9\end{array}$ & $\begin{array}{r}3190.84 \\
4 \mathrm{~b}\end{array}$ & 2.000 & 53.000 & .000 \\
\hline \multirow[t]{4}{*}{$\begin{array}{l}\text { Pengar } \\
\text { uh }\end{array}$} & Pillai's Trace & .989 & $\begin{array}{r}2296.53 \\
4 b\end{array}$ & 2.000 & 53.000 & .000 \\
\hline & Wilks' Lambda & .011 & $\begin{array}{r}2296.53 \\
4 b\end{array}$ & 2.000 & 53.000 & .000 \\
\hline & $\begin{array}{l}\text { Hotelling's } \\
\text { Trace }\end{array}$ & 86.662 & $\begin{array}{r}2296.53 \\
4 \mathrm{~b}\end{array}$ & 2.000 & 53.000 & .000 \\
\hline & $\begin{array}{l}\text { Roy's Largest } \\
\text { Root }\end{array}$ & 86.662 & $\begin{array}{r}2296.53 \\
4 \mathrm{~b}\end{array}$ & 2.000 & 53.000 & .000 \\
\hline \multicolumn{7}{|c|}{ a. Design: Intercept + pengaruh } \\
\hline \multicolumn{7}{|c|}{ b. Exact statistic } \\
\hline
\end{tabular}

Uji Multivariate digunakan untuk menguji apakah setiap faktor mempengaruhi grup variabel dependen. Berdasarkan tabel di atas hasil analisis menunjukkan bahwa nilai signifikansi baris pengaruh untuk Pillai's Trace, Wilks' Lambda, Hotelling's Trace, Roy's Largest Root adalah 0,000. Sehingga nilai Sig $0.000<0,05$ atau nilai signifikansi yang didapat $<0,005$. Sehingga diperoleh hipotesis: $\mathrm{H}_{0}$ ditolak dan $\mathrm{H}_{\mathrm{a}}$ diterima. Sehingga dapat disimpulkan "Ada pengaruh penggunaan media audio visual pada materi salat terhadap minat dan hasil belajar peserta didik".

\section{B. Pembahasan}

\section{1) Pengaruh Penggunaan Media Pembelajaran Audio Visual pada Materi Salat Terhadap Minat Belajar Peserta Dididk}

Pengaruh penggunaan media audio visual pada materi salat terhadap minat belajar peserta didik menggunakan uji $t$-Test. Sebelum melakukan uji $t$-Test data harus bersifat homogen dan berdistribusi normal. Untuk menguji data homogen dan berdistribusi normal menggunakan aplikasi SPSS 21.0 for windows dengan kriteria Sig. > 0,05. Hasil uji homogenitas data angket minat belajar diperoleh nilai Sig 0,519. Jadi data angket minat belajar homogen karena 0,519 >0,05. Uji normalitas untuk mendapatkan distribusi normal data angket minat belajar di dapatkan nilai Asymp. Sig. (2-tailed) adalah 0,998, karena 0,998 > 0,05 maka data angket minat belajar berdistribusi normal.

Uji homogenitas dan uji normalitas sudah didapatkan bahwa angket minat belajar adalah homogen dan berdistribusi normal, selanjutnya dilakukan uji $t$-Test. Uji $t$-Test juga dilakukan menggunakan SPPS 21.0 for windows. Dasar pegambilan keputusan jika nilai Sig. (2-tailed) $<0,05$, maka terdapat perbedaan yang signifikan. Jika nilai Sig. (2-tailed) $>$ 0,05 maka tidak terdapat perbedaan yang signifikan. Didapatkan data 28 orang peserta didik pada kelas VII.6 dengan mean (rata-rata) untuk audio visual 62,64 dengan nilai $t$ hitung -0,871 dengan Sig. (2-tailed) sebesar 0,000 dan untuk minat belajar dengan mean (rata-rata) sebesar 79,07 dengan nilai t hitung sebesar -0,871 dan Sig. (2-tailed) sebesar 0,000. Jadi dapat disimpulkan bahwa nilai Sig. (2-tailed) 0,000 <0,005 maka ada pengaruh yang signifikan penggunaan media audio visual pada materi salat terhadap minat belajar peserta didik. 
Menggunakan media pembelajaran audiovisual pada materi salat ternyata mampu mempengaruhi minat belajar peserta didik. Peserta didik yang awalnya memiliki motivasi rendah terhadap minat belajar materi salat, setelah dilakukan pembelajaran di kelas dengan menggunakan media pembelajaran audiovisual motivasi peserta didik menjadi meningkat ini didasarkan pada hasil temuan di atas. Jadi salah satu cara atau alternatif yang dapat dilakukan untuk meningkatkan minat belajar peserta didik salah satunya adalah dengan menggunakan media audiovisual.

\section{2) Pengaruh Penggunaan Media Pembelajaran Audiovisual pada Materi Salat Terhadap Hasil Belajar Peserta Didik}

Penelitian ini juga melihat pengaruh penggunaan media audio visual pada materi salat terhadap hasil belajar peserta didik dengan menggunakan uji $t$-Test. Sebelum melakukan uji $t$-Test data harus bersifat homogen dan berdistribusi normal. Untuk menguji data homogen dan berdistribusi normal menggunakan aplikasi SPSS 21.0 for windows dengan kriteria Sig. $>0,05$. Hasil uji homogenitas data posttest hasil belajar diperoleh nilai Sig 0,332. Jadi data posttest hasil belajar homogen karena 0,332 >0,05. Uji normalitas untuk mendapatkan distribusi normal data posttest hasil belajar di dapatkan nilai Asymp. Sig. (2-tailed) adalah 0,061 karena 0,061 > 0,05 maka data posttest hasil belajar berdistribusi normal.

Analisis selanjutnya adalah menggunakan uji $t$-Test setelah melakukan uji homogenitas dan uji normalitas. Uji $t$-Test untuk hasil belajar menggunakan SPPS 21.0 for windows. Dasar pegambilan keputusan jika nilai Sig. (2-tailed) $<0,05$, maka terdapat perbedaan yang signifikan. Jika nilai Sig. (2-tailed) $>0,05$ maka tidak terdapat perbedaan yang signifikan. Didapatkan data 28 orang peserta didik pada kelas VII.6 dengan mean (rata-rata) untuk audio visual 62,61 dengan nilai t hitung 33, 196 dengan Sig. (2-tailed) sebesar 0,000 dan untuk hasil belajar dengan mean (rata-rata) sebesar 8,61 dengan nilai $t$ hitung sebesar 33,196 dan Sig. (2-tailed) sebesar 0,000. Jadi dapat disimpulkan bahwa nilai Sig. (2-tailed) 0,000 0,005 maka ada pengaruh yang signifikan penggunaan media audio visual pada materi salat terhadap hasil belajar peserta didik.

Menggunakan media pembelajaran audiovisual pada materi salat ternyata mampu mempengaruhi hasil belajar peserta didik. Peserta didik yang awalnya memiliki hasil belajar rendah terhadap materi salat, setelah dilakukan pembelajaran di kelas dengan menggunakan media pembelajaran audiovisual hasil belajar peserta didik menjadi meningkat ini didasarkan pada hasil temuan di atas. Jadi salah satu cara atau alternatif yang dapat dilakukan untuk meningkatkan hasil belajar peserta didik salah satunya adalah dengan menggunakan media audiovisual.

\section{3) Pengaruh Penggunaan Media Audio Visual pada Materi Salat Terhadap Minat dan Hasil Belajar Peserta didik}

Melihat pengaruh penggunaan media audio visual pada materi salat terhadap minat dan hasil belajar peserta didik dilakukan dengan uji Manova (multivariat of varience) uji Manova digunakan untuk mengukur pengaruh variabel independen terhadap beberapa variabel dependen secara stimulant atau sekaligus. Uji manova juga menggunakan SPPSS 21.0 for windows. Analisis dalam uji manova melalui pengujian test of between subject effect, tes ini menguji setiap faktor terhadap variabel dependen. Melalui uji manova signifikansi yang didapat pada baris pengaruh adalah 0,000. Jika signifikansi $<0,05$ maka terdapat pengaruh atau 0,000 $<0,005$. Sehingga dapat disimpulkan bahwa ada pengaruh penggunaan audio visual pada materi salat terhadap minat dan hasil belajar pesereta didik di SMP Negeri 6 Bukittinggi.

Analisis terakhir adalah dari hasil multivariate test. Uji Multivariate digunakan untuk menguji apakah setiap faktor mempengaruhi grup variabel dependen. nilai signifikansi baris pengaruh untuk Pillai's Trace, Wilks' Lambda, Hotelling's Trace, Roy's Largest Root adalah 0,000. Sehingga nilai Sig $0.000<0,05$ atau nilai signifikansi yang didapat $<0,005$. Sehingga diperoleh hipotesis: $\mathrm{H}_{0}$ ditolak dan $\mathrm{H}_{\mathrm{a}}$ diterima. Sehingga dapat disimpulkan "Ada 
Viola Amnda dan Wirdati: Pengaruh Media Audiovisual pada Materi Shalat terhadap Minat...

pengaruh penggunaan media audio visual pada materi salat terhadap minat dan hasil belajar peserta didik.

\section{Simpulan}

Berdasarkan temuan dan pembahasan hasil penelitian, maka dapat disimpulkan bahwa media pembelajaran audio visual pada materi salat memiliki pengaruh terhadap minat dan hasil belajar peserta didik. Hal ini berdasarkan pengujian hipotesis yang dilakukan dimana $\mathrm{H}_{\mathrm{a}}$ diterima dan $\mathrm{H}_{0}$ ditolak. Dimana Ha terdapat pengaruh penggunaan media audiovisual pada materi salat terhadap minat dan hasil belajar peserta didik dan $\mathrm{H} 0$ tidak terdapat pengaruh penggunaan media audio visual pada materi salat terhadap hasil belajar peserta didik. Uji hipotesis ini dilakukan dengan menggunakan uji $t$-Test dan uji manova. Uji $t$-Test dilakukan untuk melihat pengaruh penggunaan media pembelajaran audiovisual pada materi salat terhadap minat belajar peserta didik dan pengaruh penggunaan media pembelajaran audiovisual pada materi salat terhadap hasil belajar peserta didik. Sedangkan uji Manova dilakukan untuk melihat pengaruh penggunaan media pembelajaran audiovisual pada materi salat terhadap minat dan hasil belajar peserta didik.

\section{Referensi}

Abdurrohman, A. (2017). Pengaruh Penggunan Media Audio Visual terhadap Minat Belajar pada Mata Pelajaran Fiqh Kelas IV MIN 6 Bandar Lampung (Doctoral dissertation, UIN Raden Bandar Lampung).

Afifah, K. (2015). Pengaruh Penggunaan Media Pembelajaran Audio Visual Dan Motivasi Terhadap Hasil Belajar Siswa Pada Mata Pelajaran Fiqih Di Mts Assalafi Kenteng, Kec. Susukan, Kab. Semarang Tahun Ajaran 2014/2015 (Doctoral dissertation, IAIN Salatiga).

Andayani, N., Saddhono, K., \& Mujyanto, Y. (2017). Peningkatan Kemampuan Menulis Teks Eksplanasi dengan Menggunakan Media Audiovisual pada Siswa Sekolah Menengah Pertama. Basastra, 4(2), 161-174.।

Arsyad, A. (2011). Media pembelajaran.

Arsyad, A., Sulfemi, W. B., \& Fajartriani, T. (2020). Penguatan Motivasi Shalat dan Karakter Peserta Didik Melalui Pendekatan Pembelajaran Kontekstual pada Mata Pelajaran Pendidikan Agama Islam. PTENSIA: Jurnal Kependidikan Islam, 6(2).

Asmara, A. P. (2015). Pengembangan Media Pembelajaran Berbasis Audio Visual tentang Pembuatan Koloid. Jurnal Ilmiah DIDAKTIKA: Media Ilmiah Pendidikan dan Pengajaran, 15(2), 156-178.

Bistari, B. (2017). Konsep dan Indikator Pembelajaran Efektif. Jurnal Kajian Pembelajaran dan Keilmuan, 1(2), 13-20.

Budiyono. (2009). Statistika untuk Penelitian Edisi ke-2 Cetakan ke-3. Surakarta: UNSPress.

Febliza, A., \& Afdal, Z. (2015). Statistika dasar penelitian pendidikan. Pekanbaru; Adefa Grafika.

Fttria, A. (2014). Penggunaan Media Audio Visual dalam Pembelajaran Anak Usia Dini. Cakrawala Dini: Jurnal Pendidikan Anak Usia Dini, 5(2)

Haryoko, S. (2012). Efektivitas pemanfaatan media audio-visual sebagai alternative optimalisasi model pembelajaran. Jurnal Edukasi Elektro, 5(1).

Hastuti, A., \& Budianti, Y. (2014). Pengaruh Penggunaan Media Audio Visual Terhadap Hasil Belajar Siswa pada Mata Pelajaran IPA Kelas II SDN Bantargerbang II Kota Bekasi. Pedagogik (Jurnal Pendidikan Sekolah Dasar), 2(2).

Jannah, T. A. (2020). Pengaruh Penggunaan Audio Visual terhadap Minat dan Hasil Belajar Fiqih Peserta Didik Di MA Al Muslimun Lamongan.

Jannah, T. A. (2020). Pengaruh Penggunaan Media Audiovisual Terhadap Minat dan Hasil Belajar Fiqih Peserta Didik di MA Al-Muslimun Lamongan.

Ma'rufah, A. (2020). Implementasi Kurikulum Mata Pelajaran Pendidikan Agama Islam (Upaya Mewujudkan Budaya Religius di Sekolah). EDUKASIA: Jurnal Pendidikan dan Pembelajaran, 1(1), 125-136. 
Mahnun, N. (2012). Media pembelajaran (kajian terhadap langkah-langkah pemilihan media dan implementasinya dalam pembelajaran). An-Nida', 37(1), 27-34.

Materi Hubungan Antara Sumber Daya Alam dengan Lingkungan Siswa Kelas IV SD Negeri Pasi Teungoh Kecamatan Kaway XVI. Bina Gogik: Jurnal Ilmiah Pendidikan Guru Sekolah Dasar, 3(2).

Muhson, A. (2010). Pengembangan media pembelajaran berbasis teknologi informasi. Jurnal Pendidikan Akuntansi Indonesia, 8(2), 1.

Mumtahanah, N. (2014). Penggunaan Media Visual dalam Pembelajaran PAI. Jurnal Studi Keislaman, 2014, 4.1: 91-104.

PAI, A. (1997). Pendidikan Agama Islam. Jurnal, diakses pada, 18(10), 2018

Prupuh, F., \& Sutino, S. (2007) Strategi Belajar Mengajar, Bandung: Refika Aditma.

Purwono, J. (2014). Penggunaan Media Audio-Visual pada Mata Pelajaran Ilmu Pengetahuan Alam di Sekolah Menengah Pertama Negeri 1 Pacitan. Jurnal teknologi pendidikan dan pembelajaran, 2(2).

Ramli, M. (2015). Hakikat Pendidik dan Peserta Didik. Tarbiyah Islamiyah: Jurnal Ilmiah Pendidikan Agama Islam, 5.1

Ricardo, R., \& Meilani, R. I. (2017). Impak Minat dan Motivasi Belajar terhadap Hasil Belajar Siswa. Jurnal Pendidikan Manajamen Perkantoran (JP Manper), 2(2), 188-201.

Rijal, A. S. (2020). Pengembangan Media Pembelajaran Berbasis Web untuk Meningkatkan Kreativitas Guru. Ideal: Jurnal Pendidikan Sosial dan Budaya, 6(1), 81-96.

Rofiq, M. N. (2010). Pembelajaran Kooperatif (Cooperative Learning) dalam Pengajaran Pendidikan Agama Islam. Jurnal Falasifa, 1(1), 1-14.

Rusdiana, A. (2014). Integritas Pendidikan Agama Islam dengan Sains dan Teknologi. Istek, $8(2), 123-143$.

Sahara, A. Y. (2017). Pengaruh Penggunaan Media Audiovisual terhadap Minat Belajar Siswa pada Mata Pelajaran PAI Kelas X Di Sman 1 Campurdarat Tulungagung.

Sugiono. (2015). Metode Penelitian Kuantitatif, Kualitatif dan R\&D, Bandung: Alfa Beta.

Surhayat, Y. (2009). Hubungan antara sikap, minat dan perilaku manusia. Jurnal Region, 1.3: 1-19.

Susanti, S., \& Zulfiana, A. (2018). Jenis-Jenis Media Dalam Pembelajaran. Jenis-Jenis Media Dalam Pembelajaran, 1-16.

Susilana, R., Si, M., \& Riyana, C. (2008). Media pembelajaran: hakikat, pengembangan, pemanfaatan, dan penilaian. CV. Wacana Prima.

Susilonuringsih, K. (2006). Faktor-faktor yang Mempengaruhi Minat Belajar Siswa Kelas I di SMK Yayasan Pendidikan Ekonomi (YAPEK) Gombong Tahun Diklat 2005/2006 (Doctoral dissertation, Universitas Negeri Semarang).

Undang-Undang RI No. 20 Tahun 2003 tentang Sistem Pendidikan Nasional Bab I Pasal 1.

Wirdaningsih, W., \& Mardhatillah, M. (2016). Penerapan Media Audio-Visual terhadap Keaktifan pada

Zubaidillah, M. H., \& Nuruddaroni, M. A. S. (2019). Analisis Krakteristik Materi Pelajaran Pendidikan Agama Islam di Jenjang SD, SMP dan SMA. Addabana: Jurnal Pendidikan Agama Islam, 2(1), 1-11. 